\title{
Transforming Financial Markets to Retail Investors - A Comparison of the U.S. and the German On-line Brokerage Market -
}

\author{
Carsten Holtmann, Christoph Lattemann, Stefan Strecker, Christof Weinhardt, \\ Information Systems, \\ Justus-Liebig-University of Giessen, Germany \\ Licher Strasse 70, D-35394 Giessen. \\ \{first name.last name\}@wirtschaft.uni-giessen.de
}

\begin{abstract}
Fundamental changes in private investments are currently observable for the German stock market. The importance of equities as an alternative to traditional kinds of private investments has grown remarkably and technological progress provides new ways for private investors to participate actively in the capital markets in order to take advantage in securities trading.

One of the latest developments in the area of investments in Germany seems to be the rise of ECNs. Since there is a rather large delay in development of the German brokerage market in comparison to the U.S., it is the aim of this contribution to determine (in a qualitative manner) possible future trends for the German retail brokerage market. Differences and parallels of the evolution of electronic brokerage systems in both countries will be analyzed by using the transaction phase model in order to systemize possible on-line brokers' and ECNs' strategies.
\end{abstract}

\section{Introduction}

In recent years, the importance of equities as an alternative to traditional kinds of private investments has grown remarkably ${ }^{1}$. American brokers adapted first to these changes by offering financial services and innovative trading systems based on new technologies like the Internet. Only since 1995, the so-called discount brokers have introduced innovative order routing systems in Germany which enable an easy, fast and cheap access

\footnotetext{
${ }^{1}$ E.g.: the total stock exchange turn over at all German exchanges rose from 1995 (4.134.797) to 1999 (5.094.478) (German Exchange[1999, p.10]) for more than $20 \%$.
}

to electronic exchange systems like Xetra and Sets. ${ }^{2}$ With the increasing impact of the Internet as a new convenient access channel for the market of financial products and services, the importance of those intermediaries offering brokerage services rose.

This paper focuses on the differences and parallels of the evolution of electronic brokerage systems in the U.S. and in the German stock market. Since there is a rather big delay in Germany, it is the aim of this contribution to derive (in a qualitative manner) future trends for the German brokerage retail market from the American experiences.

In the U.S., Alternative Trading Systems (ATS) have been used since 1969 (Instinet) and were able to acquired a significant market share by offering integrated electronic order routing and matching services for securities trading, by providing benefits to retail and institutional investors such as better prices and lower commissions as the traditional exchanges. Thereby, they attract not only professional but also retail investors to their systems.

The traditional American exchanges (e.g. NASDAQ) continued relying on the market maker principle (quote driven markets) instead of adopting fully electronic trading systems with an automated matching procedure. This is why new intermediaries were able to successfully enter the market and compete with the traditional exchanges realizing their chances by taking advantage of the prevailing (operational) inefficiencies caused by relatively low computerized exchange systems.

In Germany, the automation of the financial service industry is fundamentally different, i.e., those retail banks and brokers that provide on-line services offer pure order routing systems - without any price discovery and settlement functionalities - and, hence base their business model on lower commissions and higher convenience to

\footnotetext{
2 German Security Trading System: Exchange electronic trading
} system and the London stock trading system. 
their customers. Accordingly, these intermediaries do not compete with exchanges as it is the case in America but offer complementary services helping them to reach higher order flows.

In this context, the question arises whether and how existing on-line brokers will be able to play an important role in the upcoming "market for markets" in Germany. To approach this questioning, a brief overview of the German/European brokerage market is given (chapter 2), providing an identification of current customer needs and the degree of competition. By analyzing the transaction process of securities trading, the currently implemented business models of the existing intermediaries will be described and possible future strategies for on-line brokers will be derived (chapter 3). After the description of the legal framework, developments, market models and the structure of the U.S. brokerage market, in chapter 4 parallels between the U.S. and the German financial market will be analyzed. Chapter 5 presents a case study of a German on-line broker who recently chose one of the two presented alternative strategies. Chapter 6 closes the paper with some concluding remarks.

\section{The German/European stock trading market}

Retail investors in Germany regard equities no longer as long time investments, but increasingly as short time speculation. Thus, the historical differentiation between the needs of professional and private investors is vanishing. Not only traditional banks and on-line brokers but also exchanges have to pay close attention to this fundamental change and to the current needs of private investors.

In the German market for retail securities trading, the banks and brokers play a major role by providing investors with electronic trading systems to transfer orders to the nine German exchanges (the Xetra Trading System and the eight regional exchanges). More than $90 \%$ of the trading volume in German stocks are routed and matched within the Xetra trading system or traded at the floor of the Frankfurt Stock Exchange (see [1]). On-line brokers specialize on this issue by offering straight-through order routing systems via the Internet. The other exchanges offer specialized products (niches) like company issued warrants, foreign equities or other financial products.

\subsection{A market perspective}

Since 1994 - the year the first on-line broker entered the German market - nearly 850,000 on-line brokerage accounts have been opened by private investors. Research institutes expect 2.85 million accounts to be held in 2002 (see [2], p.23). At the first glance Germany seems to be a rather small market compared to the U.S., where already more than 10 million on-line broker accounts exist (see fig. 1). A different picture is given by analyzing the orders per account ratio (see [3], p.4):

\begin{tabular}{|c|c|c|c|}
\hline & 1997 & 1998 & 1999 \\
\hline \multicolumn{4}{|l|}{ Germany } \\
\hline $\begin{array}{l}\text { Number of } \\
\text { accounts (in } \\
\text { thousand) }\end{array}$ & 188 & 359 & 613 \\
\hline $\begin{array}{l}\text { Executed orders (in } \\
\text { million) }\end{array}$ & 2,5 & 6 & 11,5 \\
\hline Orders per account & 13,30 & 16,71 & 18,76 \\
\hline \multicolumn{4}{|l|}{ USA } \\
\hline $\begin{array}{l}\text { Number of } \\
\text { accounts (in } \\
\text { thousand) }\end{array}$ & 3000 & 6500 & 10000 \\
\hline $\begin{array}{l}\text { Executed orders (in } \\
\text { million) }\end{array}$ & 32,5 & 63,8 & 121,8 \\
\hline Orders per account & 10,83 & 9,82 & 12,18 \\
\hline
\end{tabular}

Figure 1: Comparative trading activity (see [3], p.30).

Figure 1 shows a very high trading activity of German investors, analyzing the ratio of "order per account" a tremendous trading activity by private on-line investors (see [4]) is revealed. Beyond that, there is a huge potential for ongoing growth: today only $7 \%$ of German adults and approximately $12 \%$ of European inhabitants invest in shares, whereas in the U.S. nearly $36 \%$ of the U.S. adults do so (see [2], p.57). Thus, Germany must be regarded as an very interesting market.

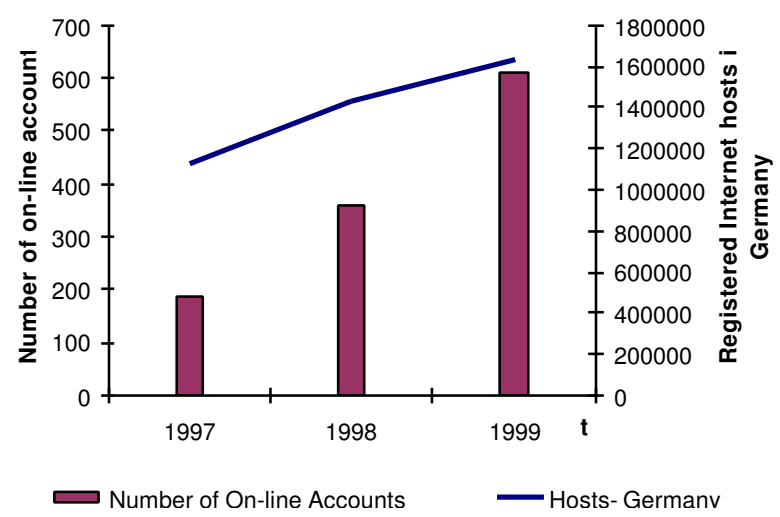

Figure 2: Comparison of registered hosts and on-line brokerage accounts in Germany (Source: [3], p.30 and [5]).

In Germany, the increasing attraction in equity trading as an alternative to traditional forms of investment (mostly saving accounts) correlates with the development of the 
on-line brokerage industry, since the relevance of stock trading and the Internet usage are growing simultaneously (see fig. 2).

Hence, it is likely that the biggest part of German retail investors will bypass the "full service" brokerage model of traditional banking and will move directly to on-line Internet trading (see [3], p.3).

\subsection{Customer segmentation}

Considering the account volume, the number of transactions and the experience of the investors, the research institute FORIT $^{3}$ distinguishes four customer segments in the German brokerage market (see [6], pp.5):

\begin{tabular}{lllll}
\hline Description & $\begin{array}{l}\text { Percentage } \\
\text { of private } \\
\text { investors }\end{array}$ & $\begin{array}{l}\text { Number } \\
\text { of } \\
\text { trans- } \\
\text { actions }\end{array}$ & $\begin{array}{l}\text { Account } \\
\text { volume }\end{array}$ & $\begin{array}{l}\text { Experience } \\
\text { in } \\
\text { Trading }\end{array}$ \\
\hline $\begin{array}{l}\text { Loyal } \\
\text { investor }\end{array}$ & $39 \%$ & Small & $\begin{array}{l}\text { Middle- } \\
\text { rate }\end{array}$ & Very small \\
\hline $\begin{array}{l}\text { Active } \\
\text { trader }\end{array}$ & $24 \%$ & Very & High & Very high \\
\hline $\begin{array}{l}\text { Portfolio } \\
\text { investor }\end{array}$ & $22 \%$ & Small & $\begin{array}{l}\text { Very } \\
\text { high }\end{array}$ & Small \\
\hline $\begin{array}{l}\text { Young } \\
\text { investor }\end{array}$ & $15 \%$ & High & Small & High \\
\hline
\end{tabular}

Figure 3: Customer segmentation in Germany.

Traditional banks and brokers used to focus on the segments "active traders" and "young investors". These were the first being attracted by the Internet and on-line brokerage. They execute most transactions per account. Accordingly, they generate the major part of the current revenues.

Due to the importance of the groups "portfolio and loyal investors" (see fig. 3), on-line brokers have to elaborate specific characteristics and financial products regarding the individual needs of each customer segment.

As fig. 4 demonstrates, the support of new distribution channels, customer consulting services and personalized information supply, cross-border and after-hours trading are the most relevant needs of those investors. On-line brokers will have to cope with these new requirements by creating new business strategies. In the remainder of this paper, it will be shown that German on-line brokers will have to take the retail investors' needs into account by offering fully integrated services to oppose the accelerating competition in the financial market.

\footnotetext{
3 FORIT GmbH Fankfurt a.M., Germany (www.forit.de).
}

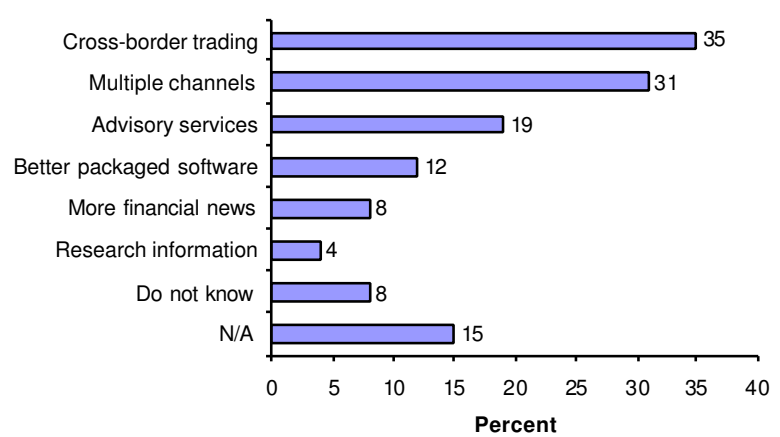

Figure 4: What brokers will add to their services (see [2], pp.63 and [7]).

\subsection{Competitive situation}

The competitive situation on the German/European on-line brokerage market is increasingly strong:

- With ConSors, ComDirect, Deutsche Bank24 and Direkt Anlage Bank (which managed about $50 \%$ of European on-line accounts in 19994) four of the five biggest on-line brokers in Europe (see [3], p.5) are based in Germany (see fig.5).

\begin{tabular}{lrr} 
& \# accounts $\mathbf{( 5 / 1 9 9 9 )}$ & market share \\
comdirect & 135.000 & $18,90 \%$ \\
ConSors & 130.000 & $15,80 \%$ \\
\hline Schwab Europe & 130.000 & $15,80 \%$ \\
DAB & 90.000 & $11,00 \%$ \\
Bank 24 & 90.000 & $11,00 \%$ \\
\hline Cortal & 74.000 & $9,00 \%$ \\
SE Banken & 50.000 & $6,10 \%$ \\
NetTrade & 18.000 & $2,20 \%$ \\
Nordnet & 13.000 & $1,60 \%$ \\
Fimatex & 11.000 & $1,30 \%$ \\
Ferry & 10.000 & $1,20 \%$ \\
Barclays Stockbrokers & 10.000 & $1,20 \%$ \\
CPR-E`Trade & 8.500 & $1,10 \%$ \\
Avanza & 8000 & $1,00 \%$ \\
Others & & $<1 \%$
\end{tabular}

Figure 5: Market shares in European on-line brokerage accounts.

- With the introduction of the Euro as a common currency in most of the European countries and the ongoing harmonization of the European financial markets, competition will increase due to the fact that the international banks try to realize their chances in this new market. Hitherto, the European stock market is still fragmented. Stocks are listed at various national and/or regional exchanges, where different organizational and regulatory frameworks exist. Some big stocks in Europe are even traded in different currencies - e.g., UK stocks since UK has not yet

\footnotetext{
${ }^{4}$ Unfortunately there is no number of trades per account available.
} 
joined the Euro network. The national markets in Europe are therefore facing a lack of transparency and liquidity compared to the US market.

- American on-line brokers will penetrate the German/ European market by introducing ECNs (e.g. Charles Schwab or $\mathrm{E}^{*}$ Trade) in order to offer after-hours and/or cross-border trading to their customers (see chapter 5).

\section{Transaction chain and integration opportunities in stock trading}

In this section, the transaction phase model is presented in order to systematize the on-line brokers' and ECNs' strategies and to derive possible strategies for on-line brokers.

\subsection{The market process and transaction phase models}

A trading process can be seen as a sequence of transaction phases as depicted in fig 6. Different phase models have been proposed to capture the semantics of trading processes ([8], pp.38; [9], pp.48; [10]). Typically, phase models for securities trading subdivide the market process into four phases: the information search, the order routing, the negotiation and the settlement phase:

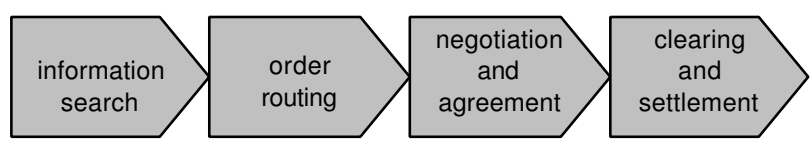

Figure 6: The market process of securities trading.

During the information phase, an investor searches information concerning market, product and counterparties. The specification of orders and the transmission to the point of execution occurs in the order routing phase. Once placed in the market, the negotiation phase starts by bringing buy and sell side together. The negotiation phase itself consists of a set of interdependent processes (see [11], p.30): trade matching, quantity allocation and price discovery. Subsequently, in the settlement phase, the contract partners exchange money and securities.

\subsection{Forward integration as a strategy for on- line brokers}

In the past, the business models of on-line brokers primarily focus on the reduction of transaction costs by using new technologies. ${ }^{5}$ Especially brokers focussed on facilitating an affordable market access for mainly retail investors by the abandoning of cost intensive consulting services, ${ }^{6}$ i.e., order routing is the core business of German on-line brokers. By supporting the order routing phase exclusively, on-line brokers developed their core competence in the discount sector and tried to realize a cost leadership position. On-line brokers quickly expanded their coverage of the transaction chain towards the information phase. Besides low transaction costs, on-line brokerage customers require information in the same quality, accuracy and speed as professional traders do. In order to meet their needs, on-line brokers were integrating professional information services to their product portfolio (see [15]). Today, they cover the information and order routing phase, but leave the negotiation and settlement phase to traditional exchanges and clearing institutions. The integration of the last two phases of the transaction chain therefore represents new possible strategies and business models.

Two complementary strategies can be identified in that respect:

1. On-line brokers integrate the negotiation phase and offer price discovery procedures in an electronic trading system;

2. On-line brokers integrate the negotiation and settlement phase and create a fully integrated computer exchange (for a classification model see [16]).

The implementation of both strategies can be observed on the U.S. market: the integration of the third phase leads to the emergence of the so-called ATS (respectively ECNs see [17]). ${ }^{7}$

The two strategies will be discussed in the context of the U.S. on-line brokerage market, to derive possible future developments in the German market.

\footnotetext{
${ }^{5}$ Transaction costs can be split up into direct and indirect costs. ,Direct costs involve commissions to brokers an stock exchanges and taxes and are known explicitly. Indirect costs are difficult to estimate. They include market impact costs (..), spread costs (..), and opportunity costs (...).“ ([12], p.36 or see [13], pp.47, [14], p.34). Transaction cost reduction nowadays is only possible because of the lower commissions of the brokers "incurred, in terms of variable costs, by the brokerage through of the Internet as a distribution channel" ([2], p.47). As an example: US-\$ 373 Merrill Lynch via broker representative; US-\$ 8 Ameritrade via the Internet (Assumes \$ 10,000 trade of 200 shares @ \$ 50 each (see [3] p.18)).

6 With this transformation costs dropped from more then $1 \%$ per transaction up to $0,2 \%$ per transaction.

7 In fact, this alternatives lead to the creation of an ECN or an exchange, depending on the legal regulations under which the emerging market operates.
} 


\section{ATS in the United States and in Germany}

The Security and Exchange Committee in the U.S.A. (SEC) defines ATS as ,automated systems that centralize, display, match, cross, or otherwise execute trading interests, but that are not currently registered with the commission as national securities exchanges or operated by registered securities association“" ([17], p.8, footnote) ${ }^{8}$

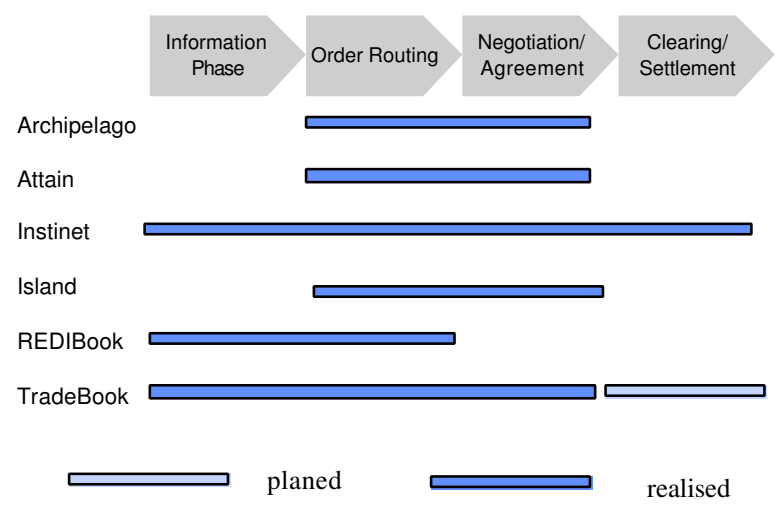

Figure 7: Process phases covered by selected ATS.

In the U.S.A., various intermediaries - ATS/ECNs and online brokers - establish platforms for security trading parallel to the existing exchanges, which link financial information services, order routing, negotiation/agreement (matching) and settlement processes.

\begin{tabular}{|l|l|l|l|l|}
\hline ECN & Target Group & & ECN & Target Group \\
\hline OptiMark & $\begin{array}{l}\text { Institutions, } \\
\text { Broker-dealers, } \\
\text { Fund Managers }\end{array}$ & & Archipelago & $\begin{array}{l}\text { Institutions, } \\
\text { Broker-dealers }\end{array}$ \\
\hline Instinet & $\begin{array}{l}\text { Broker-dealers } \\
\text { Institutional and } \\
\text { Discount } \\
\text { Brokers }\end{array}$ & & Island & $\begin{array}{l}\text { Discounters, } \\
\text { Broker-dealers }\end{array}$ \\
\hline Strike & $\begin{array}{l}\text { Day Traders } \\
\text { Institutions }\end{array}$ & & TradeBook & $\begin{array}{l}\text { Institutions } \\
\text { Broker-dealers, }\end{array}$ \\
\hline Brut & $\begin{array}{l}\text { Broker-dealers, } \\
\text { REDIBoo }\end{array}$ & $\begin{array}{l}\text { Institutions, } \\
\text { Retail } \\
\text { Brokerage, } \\
\text { Broker-dealers }\end{array}$ & NexTrade & $\begin{array}{l}\text { Discount } \\
\text { Brokers, } \\
\text { Broker-dealers, }\end{array}$ \\
\hline
\end{tabular}

Figure 8: Target groups of ECNs. Source: Internet research. ${ }^{9}$

\footnotetext{
${ }^{8}$ ATS offer services similar to those of exchanges are referred to as Electronic Communication Networks (ECN). They are not inevitably subject to the regulatory and organizational conditions of exchanges ([17]).

9 www.tradearca.com, www.attain.com, www.instinet.com,
}

Some of these ATS cover the whole transaction chain of securities trading (see fig. 7) for a wide range of customers (see fig. 8).

\subsection{Development of ATS in the U.S.}

Three main factors led to the fast emergence of ATS in the U.S.:

1. the - compared to European financial markets - low degree of automation in trading processes/ market models of the traditional exchanges, (see chapter 4.1.1.)

2. the malpractice of market makers and brokers during the crash of 1997 at the NASDAQ and (see chapter 4.1.2.)

3. the growing impact of the Internet as the driver of fundamental changes for the whole financial services industry.

Chapter 4.1.1 and 4.1.2 give a deeper insight into the development of ATS and the according regulatory framework:

\subsubsection{Structure and trading processes at American exchanges and ATS}

Traditional American exchanges (e.g. NASDAQ) missed the step in the evolution from computer supported (floor) trading to fully integrated electronic trading systems; i.e., the matching of orders and the process of price discovery is yet not fully automated. Price discovery is merely realized by the market maker principle and, hence, implicates in-transparency and high transaction costs.

ATS typically have sophisticated IT infrastructures that have been designed from scratch to support the relevant phases in the transaction process - particularly the automated matching and price discovery. This enables ATS to

- underbid the fees exchanges charge their customers,

- act more flexible to varying customer demands or market trends and

- establish themselves as competitors for the traditional exchanges.

In the end of 1999 nine ECNs were registered in the U.S.: Archipelago, Attain, TradeBook, Brass Utility, Instinet, Island, REDIBook, Strike Technology, NexTrade.

While traditional exchanges are often owned by a few and huge banks, the owner of the new trading platforms are investment banks, brokers, news agents and software companies (see [18]). This heterogeneous ownership structure guarantees a fast adaptation of the market

Www.islandecn.com, www.nextrade1.com, www.optimark.com, www.redi.com, www.strk.com, 
models, trading features and IT-architecture to the market requirements.

Typically, ATS enable cost-effective and order-driven electronic trading which circumvents the usual market makers and often focuses on specific niches like basket-, day- or after-hours trading. Private investors' needs are often better satisfied by such ATS.

\subsubsection{Malpractice by American market makers}

In the 1990s two negative trends of the NASDAQ were observed by SEC ([19]): 10

1. The bid-ask spread was suspiciously high. Moreover, limit orders, which could narrow the spread were not routed into the system by market makers and specialists. ${ }^{11}$

2. Market makers themselves traded at prices that were not accessible to the public. The posted spreads did not really represent the market prices. Only intermediaries with a direct link to the market maker systems had access to prices given by them.

The existing regulations were not sufficient to prevent this malpractice and hence a lack of efficiency resulted. For this reason, the SEC devised the new Order Handling Rule $(\mathrm{OHR})([20])$ in order to undermine the best execution principle by the market maker.

Despite the growth of their trading volume and not to suppress the innovative ATS, the SEC rolled out the Final Rule Release No. 34-40760. Since November 1998, ATS can choose whether to register

- as national securities exchanges or

- as broker-dealers, i.e., to meet special requirements with respect to transparency and supervision.

The kinds of regulation that have to be considered by the carrier of a market system depend in the U.S.

1. on the personal decision whether one wants to be regulated as an exchange or not and

2. on the objective criterion "market share in a certain product".

Additionally, ECNs are obliged to link their order books to other markets in the NMS (National Market System) to guarantee their non-broker clients the possibility of best execution at all times. This prohibits the ECNs from matching orders in-house, if a better transaction is available at better conditions in other price-generating markets. According to [17], to get registered as an ECN the following requirements have to be fulfilled:

- continuous dissemination of price information,

10 It was established that Fishman Brothers had manipulated NBBO quotes by coordinating orders routed from ATS. This is a contravention of Section 10(b) and Rule 10b-5.

11 For a detailed description of the task of the Market Maker and Specialists see ([21]).
- limit order book management or ongoing auctions, (automated) matching of client orders and their execution. The latest step concerning the vanishing of the traditional structures in the U.S. market have been established in the abolishment of rule 390a of the New York Stock Exchange (NYSE). Due to this rule, the investment banks and brokerdealers are now allowed to trade securities over the counter (OTC) which are listed at the NYSE. ${ }^{12}$

\subsection{Developments in the German Market}

The current situation in Germany is rather different from the U.S. concerning the IT infrastructure and the legal framework but similar concerning the importance of on-line brokerage and the heterogeneity and needs of private investors:

The Deutsche Terminbörse (DTB - as a company of the Deutsche Börse Group) established the first electronic trading systems in Germany in 1990. Since September 1998, Deutsche Börse AG and Swiss Exchange (SWX) are operating trading systems, DTB and SOFFEX, as a joint market called Eurex (European Exchange). Today this market is based on a unique technical platform and integrates clearing and settlement with fully harmonized rules and regulations. The Deutsche Börse AG (carrier of the Frankfurt exchange) started with IBIS (integrated exchange trading and information system) in April 1991 and rolled out the XETRA (exchange trading) system in 1997 as a fully integrated electronic trading platform ([23]). Since this exchange operates at comparably high operational efficiency - assuring low transaction costs 13 - ATS could hardly establish in Germany until now by providing a unified platform with consolidated liquidity and high transparency at low transaction costs.

Beyond this, there is a much more important reason that protects German exchanges from competition by ATS (respectively the transformation form on-line-brokers to ATS): the German regulatory framework. There is neither an explicit legal definition of an exchange nor one for any other form of trading systems. Pfüller/Westerwelle ([24]) provides a set of important criteria for the decision whether a trading system will have to be regulated as an exchange or not:

- centralization of business transactions,

- bondage upon a single place or system,

- limitation of participants and,

- way prices are discovered in the system.

12 Formerly this was forbidden for stocks being older than April 26, 1997 (see [22]).

13 The Xetra fees range from $0,0005 \%$ until $0,07 \%$ per transaction charged directly by the exchange to banks. 
In Germany, the design of the price discovery process (e.g. hit \& take, single auctions, double auctions or hybrid models) seems to be the most important criteria for regulatory aspects. The existence of an exchange needs the permission and supervision by the local government ([25]). For providing an exchange stringent requirements to fulfill the market supervision leads to high operational costs. Hence the question arises how to design an ATS as an efficient trading system on the one hand and an unregulated system on the other hand. Today, this can not satisfactorily be answered.

Following the American example of Final Rule Release No. $34-40760$, as an outcome of the $4^{\text {th }}$ "Financial market promotion act"14, 15 an alternative of regulated trading is likely to be implemented additionally to the existing framework.

This offers good chances for ATS carrier to make inroads into Germany, by focussing on special customer needs which are not provided or not sufficiently supported by existing exchanges, e.g., sophisticated systems for block trading.

With the announced merger of the London Stock Exchange and the Frankfurt Exchange more than $50 \%$ (see [27]) of the different European equity market segments could be traded over the XETRA system. With the actual market model (round lot size 100 for DAX-Stocks, no 24/7 hour trading, no direct connection to retail customers, etc.) this system primarily focus on the professional traders' needs and interests. Therefore, specializing on the needs of the active retail customers like after-hours trading and flexible choice in market models might be a profitable strategy for ATS as well as for on-line brokers. In both cases, time to market will be the most important success factor.

\section{Case Study}

Writing this paper, ConSors Discountbroker AG - the biggest German discount broker in terms of transactions adopted the before mentioned strategic alternative in an innovative manner. ConSors emphasizes the idea of 'time to market' and circumvents the existing drawbacks in the legal framework. Instead of building an ECN facing the risks mentioned above, they purchased the majority of Berliner Effektengesellschaft and will become a specialized exchange for German retail on-line investors. According to their announcements this new exchange aims at competing with the traditional exchanges which are mainly designed for professional/ institutional investors.

\footnotetext{
14 See [26].

15 A final decision and a new legal framework are not expected before mid of 2001 .
}

By implementing this solution ConSors has advantages to compete with two independent groups (other on-line broker and exchanges):

- ConSors can realize much lower cost compared to other on-line brokers, since they run a 'proprietary trading system' and can thus determine their amount of commissions. Additionally, they have the possibility to optimize the existing market models (round lot sizes, trading hours, etc.) to meet retail customer needs as aforementioned.

- ConSors already keeps 400,000 (July 2000) deposits of the most active traders in Germany. By creating an individual market model for this group of private investors, ConSors can acquire a huge amount of the order volume to the own trading systems. This assures an advantage in the competition with other (regional) exchanges in Germany. Additionally, ConSors is well prepared for the ongoing competition with other national and international exchanges or ATS.

Since liquidity is the overall requirement of trading systems, ConSors is overcoming a pure competitive strategy, by announcing possible co-operations in the future. With these steps, ConSors might be able to realize an early mover advantage in the battle for liquidity in the 'market for markets' by employing a 'co-opetition strategy'.

Nevertheless, with such a trading system, liquidity will be fragmented and thus will decrease the degree of market transparency. Furthermore, the clients of such proprietary trading systems are bundled to the providers and implying high dependencies.

\section{Conclusions}

Even if the market structure and legal differences prohibit a direct transfer of aspects gained from the U.S. to the German market, yet, the analysis of the U.S. market provides important insights concerning the future strategy of on-line brokers in Germany. Fundamental differences in the regulatory framework, in the market (micro) structure, and in the degree of automation must be taken into account. However, the underlying transaction phase model and the retail investors' requirements of both markets are similar and thus form a common basis, which allows us to assume, that the observation of the developments in the U.S. retail brokerage markets can be utilized to generate potential future strategies for German on-line brokers. Based on the alternative strategies proposed in chapter 3, strong evidence in the U.S. markets suggest German on-line brokers to forward the integration of transaction phases by expanding their services. This expansion can be accomplished by the implementation of an exchange or ATS respectively. 


\section{References}

[1] German Exchange, Fact Book 1999. Frankfurt am Main, 1999.

[2] Datamonitor, IT in European Retail Brokerage: The Online Revolution. Financial Service Research Program, Datamonitor, London, 2000.

[3] J.P.Morgan, Internet Broking: Unstoppable. J.P.Morgan, London, 1999.

[4] Schoyer, W., “The On-line Brokerage Industry.” In: http://www.mcafe.com/pantry/bps_042699.html, (05-081999).

[5] Denic, http://www.denic.de/images/ diagramme/Hosts_fancy_de.xls, (28-09-2000).

[6] Forit,Broker@ge.de: Internet- und Online-Brokerage für Privatkunden in Deutschland. FORIT, Frankfurt, 2000.

[7] Forrester Research, Online Trading Skyrockets in Europe. Forrester Research Inc., Cambridge, 2000.

[8] Schmid, B.F., "Elektronische Märkte - Merkmale, Organisation und Potentiale.” In: Hermanns, A., Sauters, M., Management Handbuch Electronic Commerce. Vahlen, München, 1999.

[9] Cohen, K.J.; Maier, S.F.; Schwartz, R.A.; Whitcomb, D.K., "Electronic Trading and the Stock Exchange of the Future.” In: Cohen, K.J., Maier, S.F., Schwartz, R.A. Whitcomb, D.K., The microstructure of securities markets. Englewood Cliffs, New York, 1986.

[10] Picot, A.; Bortenlänger, Ch.; Röhrl, H., Börsen im Wandel. Fritz Knapp, Frankfurt am Main, 1995.

[11] Domowitz, I., "Automating the continuous double auction in practice: automated trade execution systems in financial markets." In: Friedman, D. Rust, J., The double auction market - Institutions, theory and evidence. AddisonWesley, Reading, 1993.

[12] Konana, P.; Menon, N.M.; Balasubranmanian, S. "The implications of online investing." In: Communications of the ACM, Vol. 43, January 2000, No.1, pp.35-41.

[13] Gomber, P., Elektronische Handelssysteme: innovative Konzepte und Technologien im Wertpapierhandel. PhysicaVerlag, Heidelberg, 2000.

[14] Konana, P.; Menon, N.M.; Balasubranmanian, S., "Electronic Brokerages for Online Investing.” In: Electronic Markets, Vol. 9 (2000), No. 1/2, 1999, pp.32-36.

[15] Weinhardt, Ch.; Gomber, P.; Holtmann, C., "Transforming professional markets to retail investors." In: Locarek-Junge, H.; Walter, B. (Hrsg.): Banken im Wandel:
Direktbanken und Direct Banking. Band 18, Berlin Verlag, Berlin, 2000.

[16] Schenk, N., Informationstechnologie und Börsensysteme. Gabler, Wiesbaden, 1997.

[17] SEC, "Regulation of Alternative Trading Systems";

Suspension (Extension of Effective Date to December 1, 2000) Dated: March 31 $1^{\text {st }}$, 2000[Release No. 34-42603A; File No. S712-98], 1997.

[18] Dornau, R., Alternative Trading Systems in the United States and in Europe. Deutsche Börse AG, Frankfurt, 1999.

[19] SEC, U.S. Securities Exchange Act Release No. 40115 (24-06-1998), 1998.

[20] NASDAQ, “Order Handling Rules”. In: http://www.nasdaq.com/about/oh-rules.stm, (28-06-2000).

[21] Schwartz, R.A., Reshaping the Equity Markets. A Guide for the 1990s. Harper Business, New York, 1991.

[22] Sales, R., “The quest to kill 390.” In : Wall Street \& Technology, December 1999; pp.207-208.

[23] Braue, C.; Hille, L., "XETRA - Elektronische Handelssysteme am Finanzplatz Deutschland.” In: Die Bank, 3/1997, pp.140-145.

[24] Pfüller, M.; Westerwelle, K., "Wertpapierhandel im Internet”. In: Handbuch für Multimediarecht, Beck, Teil 13.7., 1999.

[25] German Exchange Law[1998] as of January $1^{\text {st }}, 1998$.

[26] Hopt, K.J.; Rudolph, B.; Baum, H.[eds.], Börsenreform - eine ökonomische, rechtsvergleichende und rechtspolitische Untersuchung. Schäffer-Poeschel, Stuttgart, 1997.

[27] Deutsche Börse AG, "Deutsche Börse und London Stock Exchange schließen sich zusammen.” In: http://www.media-relations.exchange.de, (15-06-2000), 2000. 